\title{
Magnesium pemoline: Facilitation of one way and two way avoidance learning
}

RICHARD $W$. THOMPSON AND GARY R. KNUDSON, DEPARTMENT OF PSYCHOLOGY, WESTERN WASHINGTON STATE COLLEGE, Bellingham, Wash. 98225

Rats injected with magnesium pemoline required fewer trials to reach criterion on both a one way and two way avoidance task. However, there was no effect of the drug on latency measures. Magnesium pemoline did not appear to have its facilatory effect by reducing freezing or decreasing response latency.

Recent experiments have demonstrated facilitated avoidance performance in rats treated with magnesium pemoline (MP). The original interpretation of these results was that MP enhanced learning by enhancing brain RNA (Glasky \& Simon, 1966; Plotnikoff, 1966). More recent experiments have indicated that facilitated performance was a result of the CNS stimulating effects of MP (Kulkarni, 1967; Powell, Martin, \& Kamano, 1967). An alternative interpretation is that MP effects performance by decreasing freezing response (Beach \& Kimble, 1967; Frey \& Polidora, 1967).

Vanderwolf (1963) has shown that Ss given a pre-training series of electroconvulsive shocks will show improved performance on a two way avoidance task but no improvement on a one way task the improvement being a result of a reduction in the freezing responses that usually occur in the two way task (Theios, Lynch, \& Lowe, 1966). The present experiment investigated the effect of MP on avoidance learning in rats trained on one way or two way avoidance tasks.

Subjects. The Ss were 36 male, albino, Sprague-Dawley rats approximately 90 days old at the time of the experiment. Ss were housed in individual cages and had ad lib food and water throughout the experiment.

Apparatus. The apparatus was a $36 \times 14 \times 4 \frac{1}{2}$ in. wide (inside dimensions) shuttle box divided in half by a $3 \frac{12}{2}$ in. wide guillotine door. The box was painted flat black except for a $1 \frac{3}{4}$ in. wide observation window, even with the grid floor, which ran the length of the box. The grid floor was of $1 / 8$ in. brass rods $5 / 8$ in. center to center. The grid could be charged with $1.4 \mathrm{~mA} \mathrm{dc}$ current from a C. J. Applegate stimulator through a Grason-Stadler grid scrambler. A $70 \mathrm{~dB}$ buzzer rested on the table behind each end of the shuttle box. Background noise was $60 \mathrm{~dB}$. Raising of the guillotine door and buzzer onset were hand operated. The CS-US interval and shock onset were controlled by a Hunter timer. A Standard Electric clock that started with CS onset and stopped with CS termination measured response latency. The ITI was timed with a stop watch.

Procedure. The Ss were divided into two equal groups; the experimental group received $20 \mathrm{mg} / \mathrm{kg}$ of MP $(10 \mathrm{mg} / \mathrm{cc})$ in $0.3 \%$ tragacanth, and the control group received an equal volume of the tragacanth carrier. Both groups received injections, IP, $30 \mathrm{~min}$ before training began.

Both control and experimental groups were further divided, half of each group being trained on the one way and the other half being trained on the two way avoidance task. For both tasks the CS was onset of the buzzer at the end of the apparatus where $S$ was at the beginning of the trial and the opening of the guillotine door. The CS-US interval was $5 \mathrm{sec}$ and both CS and US were response terminated. The ITI was $60 \mathrm{sec}$. In the one way task, the S ran in only one direction and was returned to the shock side of the apparatus after $45 \mathrm{sec}$ in the nonshock side. The two way task was like the typical shuttle task except the $S$ was picked up and turned to face the guillotine door $15 \mathrm{sec}$ before CS onset. The guillotine door prevented ITI shuttling for both groups. All Ss were trained to a criterion of nine avoidance responses in 10 consecutive trials or for a maximum of 100 trials.

Table 1

Mean Trials to Criterion and Standard Deviations for both Task and Drug Conditions

\begin{tabular}{lccrrr} 
& \multicolumn{2}{c}{ One Way } & & \multicolumn{2}{c}{ Two Way } \\
\cline { 2 - 3 } \cline { 5 - 6 } Drug Condition & $\overline{\mathrm{X}}$ & $\mathrm{S}$ & & $\overline{\mathrm{X}}$ & $\mathrm{S}$ \\
\hline Magnesium Pemoline & 13.56 & 4.48 & & 61.00 & 24.47 \\
Tragacanth Only & 19.44 & 7.78 & & 84.11 & 20.76 \\
\hline
\end{tabular}

Results and Discussion. Mean and standard deviation for trials to criterion for each group are presented in Table 1. Trials to criterion for each $\mathrm{S}$ was used to compute a two factor analysis of variance. The analysis yielded a significant difference between tasks $(\mathrm{F}=101.84, \mathrm{df}=1 / 32, \mathrm{p}<.001)$ for both experimental and control groups, the one way Ss requiring fewer trials to reach criterion than the two way Ss. These data are consistent with those of Thompson \& Hjelle (1965) using similar tasks and procedures. Ss receiving MP reach criterion in significantly fewer trials than the control Ss $(F=6.81$, df $=1 / 32, p<.025)$. The interaction between task and drug conditions, which would be expected if MP served to reduce freezing responses, was not significant. These data indicate that MP facilitated learning and/or performance in both tasks equally.

To further clarify the reason for the superiority of the drug group to the control group, the first shock escape trial latency for each $S$ was used to compute a second two factor analysis of variance. Neither main effects nor the interaction reached significance. Because seven of 18 MP treated Ss showed 1.4 avoidance responses before being shocked and only three of 18 of the control Ss showed such spontaneous avoidances, a third two factor analysis of variance was computed using first trial latencies including spontaneous avoidances. This analysis also resulted in no significant main effects or interaction. As a final check on the hypothesis that the superior performance of the MP treated Ss was a result of increased activity or decreased freezing (freezing responses should result in longer latencies), a fourth two factor analysis of variance was computed using the mean pre-criterion latency of each $\mathrm{S}$ as scores. Neither the main effects nor the interaction were significant in this analysis.

Failure to find a differential effect of MP on the one way and two way tasks comparable to that found by Vanderwolf (1963) and failure to find significantly shorter latencies for the drug treated Ss, suggests that MP does not facilitate performance by reducing freezing.

The superior performance of MP treated Ss on both tasks could be a result of increased sensitivity to either the CS or US or both (Beach \& Kimble, 1967; Frey \& Polidora, 1967). The data from this experiment do not permit discounting a direct effect of MP on the learning process, although data from other experiments make this explanation unlikely.

\section{REFERENCES}

BEACH, G., \& KIMBLE, D. P. Activity and responsivity in rats after magnesium pemoline injections. Science, 1967, 155, 698-701.

FREY, P. W., \& POLIDORA, V. J. Magnesium pemoline: Effect on avoidance conditioning in rats. Science, 1967, 155, 1281-1282.

GLASKY, A. J., \& SIMON, L. N. Magnesium pemoline: Enhancement of Brain RNA polymerases. Science, 1966, 151, 702-703.

KULKARNI, A. S. Magnesium pemoline: Faciliation of instrumental avoidance learning. Psychon. Sci., 1967, 9, 39-40.

PLOTNIKOFF, N. Magnesium pemoline: Enhancement of learning and memory of a conditioned avoidance response. Science, 1966, 151, 703-704.

POWELL, B. J., MARTIN, L. K., \& KAMANO, D. K. Magnesium pemoline: Effects of training vs testing of an avoidance response. Psychon. Sci, 1967, 8, 205-206.

THEIOS, J., LYNCH, A. D., \& LOWE, Jr., W. F. Differential effects of shock intensity on one-way and shuttle avoidance conditioning. J. exp. Psychol, $1966,72,294-299$.

THOMPSON, R. W., \& HJELLE, L. A. Effects of stimulus and response complexity on learning under bilateral spreading depression. J. comp. physiol. Psychol, 1965, 59, 122-124.

VANDERWOLF, C. H. Improved shuttle box performance following electroconvulsive shock. J. comp. physiol. Psychol., 1963, 56, 983-986.

$$
\text { NOTE }
$$

1. The magnesium pemoline used in this study was supplied by Dr. H. G. Schoepke of Abbott Laboratories. 